\title{
Profile and clinical indicators of an anticoagulation domiciliary program in Bogota
}

\author{
Perfil e indicadores clínicos en un programa domiciliario de anticoagulación en Bogotá \\ Perfil e indicadores clínicos de um programa de assistência domiciliar de anticoagulação \\ em Bogotá
}

\author{
Julián Eduardo Gómez-Leal* \\ Jorge Emilio Nieto-Martinez ${ }^{* *}$ \\ Camila Clavijo-Cubillos ${ }^{* * *}$
}

\begin{abstract}
Autor de correspondencia
* Nurse and nurse master. Assistant Professor. National University of ColombiaBogota- School of Nursing- Nursing Department -Research Group of Emergencies and Critical Care. Email: jegomezl@unal. edu.co. Orcid: https://orcid.org/0000-00024002-8716

** Nurse and specialist in Emergency Nursing at the University Health Science Foundation- FUCS. Nurse from the emergency service at the Fundacion Cardio Infantil in Bogota and professor at the Nursing School in the Health Sciences University Foundation - FUCS. Email: Jnietoe@cardioinfantil.org. Orcid: https://orcid.org/0000-0003-15100314

*** Nurse and specialist in Emergency Nursing from the Health Sciences University Foundation - FUCS, Master in Education, Nurse at the San Ignacio University Hospital. Email: camyclavijo@hotmail.com. Orcid: https://orcid.org/0000-0002-7399-3504
\end{abstract}

Este es un artículo bajo la licencia CC BY

(https://creativecommons.org/ licenses/by/4.0/) @) (1)

\begin{abstract}
Objective: Describe the profile and clinical indicators of people from a domiciliary anticoagulation program in the city of Bogota, during a year of monitoring. Materials and methods: Quantitative study of descriptive scope. The population was made of 66 people from the program, who met the inclusion criteria and were cared for a year. Some of the measured variables were: type of anticoagulant, anticoagulation indications, functional compromise, risk of bleeding and time in therapeutic range. The information was obtained from monthly statistics from the program, univariate analyzed, reporting frequency distributions and ethical aspects were protected for the health research. Results: 66 patients older than 60 years of age that received Warfarin were attended and the main symptom was atrial fibrillation. The patients reached the therapeutic target in the first 9 days, achieving $70 \%$ of time in the therapeutic range, and no adverse events were presented although being at intermediate-high risk of bleeding, severe functional detriment and high comorbidity. Conclusion: The permanent monitoring of coagulation time, availability of additional controls, fast adjustments in the anticoagulation doses, health education and a direct communication channel between the patient, the family, and the healthcare team, could improve the clinical indicators of anticoagulated patients.
\end{abstract}

Keywords: Anticoagulants, patients, domiciliary visit, nursing care

\section{Resumen}

Objetivo: Describir el perfil e indicadores clínicos de las personas pertenecientes a un programa domiciliario de anticoagulación en la ciudad de Bogotá, durante un año de seguimiento. Materiales y métodos: Estudio cuantitativo de alcance descriptivo. La población estuvo integrada por 66 personas pertenecientes al programa, quienes cumplieron los criterios de inclusión y fueron atendidas durante un año. Algunas variables medidas fueron: tipo de anticoagulante, indicación de anticoagulación, compromiso funcional, riesgo de sangrado y tiempo en rango terapéutico. La información fue obtenida de la estadística mensual del programa, analizada de forma univariada, reportando distribución de frecuencias, y se salvaguardaron los aspectos éticos para la investigación en salud. Resultados: Se atendieron 66 pacientes mayores de 60 
años que recibían warfarina y la indicación principal fue fibrilación auricular. Las personas alcanzaron la meta terapéutica en los primeros 9 días, logrando un $70 \%$ del tiempo en rango terapéutico, y no se presentaron eventos adversos a pesar de tener riesgo intermedio-alto de sangrado, deterioro severo de la funcionalidad y alta comorbilidad. Conclusión: El monitoreo permanente de tiempos de coagulación, disponibilidad de controles adicionales, ajustes rápidos en la dosis de anticoagulante, educación en salud y un canal directo de comunicación entre el paciente, la familia y el equipo de salud, podrían mejorar los indicadores clínicos de las personas anticoaguladas.

Palabras Clave: Anticoagulantes, pacientes, visita domiciliaria, atención de enfermería.

\section{Resumo}

Objetivo: Descrever o perfil e indicadores clínicos das pessoas que conformam um programa de assistência domiciliar de anticoagulação na cidade de Bogotá, realizada em um ano de acompanhamento. Materiais e métodos: Estudo quantitativo descritivo. A amostra esteve composta por 66 pessoas que pertenceram ao programa e foram acompanhadas por um ano. Algumas variáveis aferidas foram: tipo de anticoagulante, indicações da anticoagulação, comprometimento funcional, risco de sangramento e tempo no rango terapêutico. As aferições realizaram-se todo mês e a análise realizou-se de forma univariada, reportando distribuições de frequências. Foram considerados os aspectos éticos para a pesquisa em saúde. Resultados: Atenderam-se 66 pessoas maiores de 60 anos que receberam warfarina e a indicação foi o diagnóstico de fibrilação auricular. As pessoas conquistaram as metas terapêuticas e não apresentaram complicações nos primeiros 9 dias de tratamento, além de obter $70 \%$ de tempo do rango terapêutico. Também não houve eventos adversos embora o risco intermeio-alto de sangramento, deterioro da funcionalidade ou alta morbidade. Conclusão: $O$ acompanhamento permanente dos tempos de coagulação, a disponibilidade de atendimentos adicionais, ajustes rápidos nas dosagens do anticoagulante, a educação em saúde e a comunicação direta entre o paciente à família e a equipe de saúde, poderão melhorar os indicadores clínicos das pessoas anticoaguladas.

Palavras-chave: Anticoagulantes, pacientes, assistência domiciliar, cuidados de enfermagem.
E-ISSN 2322-7028

Vol. 16 No. 3

Sep - Dic 2019

Cúcuta, Colombia

\section{Introduction}

Venous thromboembolism, mainly Deep vein thrombosis (DVP), and pulmonary embolism (PE), in addition to factors such as atrial fibrillation (AP), cardiac valve replacement, ischemic stroke and coagulation disorders, become increasingly frequent indicators for the use of oral anticoagulants.

DVP and EP occupy the first places of morbimortality, along with heart attack, stroke, coronary artery disease, and shock (1).

According to studies, the incidence of venous thromboembolism is of 117 cases per 100,000 inhabitants, and with age, the number of cases increases significantly (2). Also, it's the third cause of cardiovascular disease in Europe and North America. For the specific case of EP, the incidence is estimated to be 95 per 100,000 inhabitants (3).

In the case of atrial fibrillation, this is globally considered the most prevalent sustained supraventricular tachycardia, affecting 1 to 2 percent of the popula- tion, representing a serious public health problem due to the impact in survival and life quality of the patients (4).

In the case of heart valve disorders, the aortic stenosis is currently the disease that most frequently determines a valve replacement (5), after the immediate post-operatory it becomes an absolute indication of anticoagulation.

In relation to strokes, the World Health Organization (WHO) reassures it caused 15 million deaths in 2015, and along with coronary artery disease, have been the main cause of mortality for the last 15 years (6). The calculated incidence for Latin America varies between 35 and 183 cases per 100,000 inhabitants. In Colombia, a study made in Antioquia reported dan annual incidence adjusted by age and gender of 88.9 cases per 100,000 inhabitants, affecting more men than women (7).

Thrombophilia is defined, as a coagulation disorder that increases the predisposition of formation of blood clots, significantly increasing the morbidity 
ISSN-PRINT

1794-9831

E-ISSN 2322-7028

Vol. 16 No. 3

Sep - Dic 2019

Cúcuta, Colombia and mortality and presenting a prevalence between $1-3 / 100,000$ people, annually (8).

Oral anticoagulants were discovered at the beginning of the twentieth century and have been constituted as the main therapy for more than 50 years (9), prescribed for venous thromboembolism (DVP, EP), atrial fibrillation, arterial thrombosis, ischemic stroke, mechanical valve replacement and thrombophilia (10, 11).

Warfarin is known as one of the most used anticoagulants, in virtue of its high efficiency. However, the limitations for its use are known, such as the narrow therapeutic range and its fluctuation, the risk of bleeding due to over anticoagulation, the interactions with other medicine and foods, and also the necessity of regular monitoring from the International Normalized Ratio (INR) $(12,13)$.

In that sense, a study of cost- effectiveness described that, traditionally, oral antagonists of vitamin $\mathrm{K}$ (AVK) have been used for this purpose, but require frequent adjustments and have a strict therapeutic interval that makes its usage difficult, therefore substitutes have been searched, introducing to the medical practice in the last decade new oral anticoagulants (NACO), at least as effective as AVK, but with a higher price (14).

An ideal oral anticoagulant should be administered in fixed doses, with less interactions, greater efficiency and high security, this way decreasing the risks of hemorrhage, without needing such strict control as required by AVK, and overall, have an antidote to revert its effect in case of emergency (15).

Parallel to the search of an ideal medicine, healthcare providers have designed and implemented accompanying programs for anticoagulated patients, which are performed both in the hospital (ambulatory) and also, for a few years at the residence of the patient.

These programs are called "clinics or anticoagulation programs" and are built by an interdisciplinary team whose main goal is to guarantee the success of the anticoagulation therapy through comprehensive care of the person, with strategies such as periodic medical evaluation, accompaniment, education and permanent monitoring.

An example of this program, in Colombia, is develo- ped at the Vicente de Paul University Hospital, which claims that the key point strategy used by its anticoagulation clinic focused on verifying and establishing the therapeutic indication, defining the time and duration of the anticoagulation therapy and the therapeutic range in which the INR wants to be maintained, as well as providing education both to the patient and the person or family member in charge of its care, evaluating the adherence and constant vigilance of new thrombotic events and bleeding (16).

Another example is the Anticoagulation Clinic of the Clinical Foundation of the Valle de Lili, which bases their interventions in education, control and followup of the patients receiving Warfarin. Also, the experience at the Anticoagulation Clinic at the Fundacion de Santa Fe University Hospital in Bogota, which between 2008 and 2012 has attended 159 patients (17).

Finally, in the city of Bogota, the anticoagulation program aimed for this study, orientates its program towards people with reduced functional abilities, a phenomenon that impedes access to hospital healthcare providers, leading to providing care at the place of residence of the patient.

Domiciliary care in Colombia is defined, according to the current regulations, as an independent and autonomous service of a healthcare provider for the handling of acute or chronic patients in the domiciliary environment, with controlled criteria, in which activities and procedures proper of health care services are developed, provided in the place of residence of the patient, with the support of professionals, specialists, and the participation of the family or caregiver (18).

The anticoagulation program of the healthcare provider object of study, differentiates from the others because it is performed at the residence of the patient, oriented to the anticoagulated patient and specially to the caregivers, since most of the time they are in charge of administering the medicine and the diet, and also of being the first to recognize alarm symptoms of hypercoagulation or over anticoagulation. The program is in charge of an internist, a postgraduate nurse and two nursing assistants with specific training in the area. The criteria a person must meet to get into the program are: have a Barthel scale lower or equal to 60 and presenting a pathology that requires anticoagulant therapies. 
Every person that gets into the program, along with their family or caregivers, receive health education focusing on aspects related to the safe use of anticoagulants, indications, therapy duration and alarm symptoms. The domiciliary education and attention have an important role in health since the declaration of Alma-Ata in 1978, where its stated that health must be provided to the residence reside and work of people and that one of its main activities must be the education about the main health problems and prevention methods, and the correspondent fight against the disease (19).

Health education is given by the nurse during the home visit and reinforced through a pamphlet designed with simple language, which contains all the elements exposed in the visit. This domiciliary visit has demonstrated to be an ideal scenario to work on the health-disease process of the population, in their natural habitat, through the promotion of health and the prevention of the disease, allowing an exchange of information, experiences and abilities between the health staff and the users (20).

Also, the patient or the caregiver is included in a WhatsApp group chat, administered by the nurse of the program, whose only purpose is for the patients or their family to consult about therapy questions, alarm symptoms or novelties that come up during the process, this way guaranteeing a direct communication channel.

In the punctual case of people in therapy with Warfarin, the education provided in the home visit includes the specifications and the therapeutic target range established by the INR, time of administration of the medicine, diet care, interactions with other medicines, precautions with daily life activities and alarm symptoms.

Posterior to the home visit, an INR control and prothrombin time (PT) are performed every 72 hours during the first 10 days and later every month for the duration of the therapy. This control is performed immediately through a device called coagulometer.

The coagulometer is a portable biomedical equipment, easy to use, which allows the rapid processing of blood tests, throwing specific results of levels of INR and PT. The system measures PT with only one drop of capillary blood processed by a strip with reactive chemicals (21).
The result is reported by the nurse assistant, initially online through the WhatsApp application to all the health team members that lead the program, in a second group designed for this purpose, which allows immediate decisions and defining the next action.

Through a phone call made by the nurse, the patient or family member receive the report of the INR and the indications to follow. This way, guaranteeing immediate information to the patient, the family or the caregiver. According to each case, they receive indications of higher or lower doses of warfarin, suspending it or even moving the patient to the emergency service. Subsequently, it is registered in the medical history of the patient, which operates through a software that can be accessed on any computer that has internet connection.

If needed, additional check-up appointments are given and, finally, the interdisciplinary team meets monthly with the purpose of analyzing the clinical behavior of each person, in a process called clinical journal, which also stays registered in the medical history.

In this program, nursing care takes special importance, since it assumes that the fundamental pillar of care for the anticoagulation patient s health education, the permanent monitoring and a direct communication channel between the health workers and the patients. All these activities are responsibility of the professional nursing staff.

People with anticoagulation therapy different than Warfarin, meaning heparins of low molecular weight or new oral anticoagulants, also receive all the specific health education process for these medicines, home visits, follow-up of adherence, complications and periodic monitoring of renal physiology, that are taken at the residence and, as well as the last group, are presented monthly in the clinical journal

All the information is product of the behavior of the program, including results, indicators, news and adjustments, besides being registered on the medical history, it is also kept in a database that gives place to the monthly statistics of the program, whose analysis motivated the development of the present study through the research question: what is the profile and results of the clinical indicators of people that are members of an anticoagulant domiciliary program in the city of Bogota, during a year of follow-up? 
ISSN-PRINT

1794-9831

E-ISSN 2322-7028

Vol. 16 No. 3

Sep - Dic 2019

Cúcuta, Colombia
This work justifies its results due to the lack of studies in literature that report results of anticoagulation programs performed in the residence of the patients. Domiciliary attention is new and, more frequently, is becoming an alternative for the care of people with diverse pathologies and the need for monitoring. Therefore, documenting these experiences through research takes great importance.

Internationally some programs are described as operated by outpatient visits and led by pharmacists, who decreased hemorrhage rates and thromboembolic events. Also, its demonstrated that these can reduce the number of hospitalizations and visits to the emergency room up to $73 \%$ (22).

The anticoagulation programs or clinics in Colombia have been constituted as a strategy legislated by the resolution 2003 of 2014 (17), within the services of specific protection or early detection, which are expected to favor a decrease of adverse events, improve the adherence to the treatment and lower hospitalization days optimizing economic resources. Facing this situation, programs must be object of study for the interest of documenting the health results and impact in people.

\section{Objective}

Describe the profile and clinical indicators of people belonging to an anticoagulation domiciliary program in the city of Bogota, during a year of follow-up.

\section{Materials and methods}

Quantitative study of descriptive scope. The population corresponded to the total of people (99), attended for a year in a domiciliary anticoagulation program in the city of Bogota, between November 2016 and October 2017 . The sample was made by 66 people who received uninterrupted therapy with warfarin only during the same year.

The inclusion criteria were: being member of an anticoagulation program at the healthcare provider that was object of study, being anticoagulated with warfarin and have attended controls from the program uninterruptedly from November 2016 and October 2017. Also, the exclusion criteria were: being anticoagulated with a therapy different from warfarin, having entered the program outside the established terms for the study or having interrupted controls due to hospitalization, moving to another city or death.

The information was obtained from the monthly statistics, database, and indicators from the anticoagulation program of the healthcare provider and consigned in an information matrix designed for this research. An independent statistical analysis was used, from the frequency distributions using Microsoft Office Excel 2013. For this process the following steps were made: 1) Identifying the admission profile of people to the anticoagulation program, formed by the variables of age, gender, medical diagnosis, functional compromise, comorbidity index, INR of admission and risk classification of intermediate bleeding using the HAS-BLED Score. 2) Description of clinical indicators which include the number of days to achieve the INR therapeutic target, percentage of the year in where the therapeutic range was maintained (time in therapeutic range) and the number of adverse events.

This research respected the ethical principles for health research in Colombia, contemplated in the Resolution 8430 of 1993 . It was considered a minimal risk research (23) and the respect for the dignity of people and human rights were guaranteed, reassuring that the recollected information would only be used with academic and scientific ends. The identity of the patients is reserved, omitting their names or identification number. The study was put for consideration and approved by the university Research Ethics Committee, through the Act 013 from October 12, 2017. as well as the approval from the healthcare provider for the study. The people were informed about the program and accepted their voluntary participation by signing a consent agreement.

Also, intellectual property and copyright were guaranteed by the Law $44 / 1993$.

\section{Results}

The total of people attended in the anticoagulation domiciliary program of the health care provider object of study, during a process from November 2016 to October 2017, was of 92. The most used type of therapy was Warfarin, with $72 \%$ of the total of patients (See Table 1). 
Table 1. Frequency distributions and percentages by type of anticoagulant of people attended by the domiciliary program. Bogota, Colombia.

\begin{tabular}{ccc}
\hline Type of anticoagulant & Frequency & Percentage \\
\hline Apixaban & 4 & $4,3 \%$ \\
\hline Dabigatran & 6 & $6,5 \%$ \\
\hline Enoxaparin sodium & 7 & $7,6 \%$ \\
\hline Rivaroxaban & 9 & $9,8 \%$ \\
\hline Warfarin & 66 & $71,7 \%$ \\
Total & $\mathbf{9 2}$ & $\mathbf{1 0 0} \%$ \\
\hline
\end{tabular}

Source: Research results.

The $72 \%$ of people attended in the program for anticoagulation therapy with Warfarin that met the inclusion criteria for this research corresponds to a total of 66 patients, in which 70\% were women and 30\% men.
In relation to age of the patients, it was found that $1000 \%$ are older than 60 years, which significantly affects the morbidity and bleeding risk (See Table 2).

Table 2. Frequency distributions and percentages, according to the age range of the patients. Bogota, Colombia.

\begin{tabular}{ccc}
\hline Age range & Frequency & Percentage \\
\hline 61 to 70 years & 11 & $16,7 \%$ \\
71 to 80 years & 22 & $33,3 \%$ \\
81 to 90 years & 30 & $45,5 \%$ \\
91 to 100 years & 3 & $4,5 \%$ \\
Total & $\mathbf{6 6}$ & $\mathbf{1 0 0 , 0 \%}$ \\
\hline
\end{tabular}

Source: Research results.

In relation to anticoagulation indications, atrial fibrillation is the predominant phenomena with $43.9 \%$ of the cases, followed by ischemic stroke and DVT. It is important to notice that $42 \%$ of people present more than one indication of being anticoagulated, noticeably compromising the comorbidity of this population (See Table 3).

Table 3. Frequency distributions and percentages about the anticoagulation indication according to the medical diagnosis of the patients. Bogota, Colombia.

\begin{tabular}{ccc}
\hline Medical diagnosis & Frequency & Percentage \\
\hline AF & 29 & $43,9 \%$ \\
Stroke + AF + mechanical mitral valve & 11 & $16,7 \%$ \\
Stroke + AF & 7 & $10,6 \%$ \\
Stroke+ DVT & 7 & $10,6 \%$ \\
Mechanical mitral valve prosthesis & 5 & $7,6 \%$ \\
PE & 3 & $4,5 \%$ \\
PE + DVT & 3 & $4,5 \%$ \\
DVT & 1 & $1,5 \%$ \\
Total & $\mathbf{6 6}$ & $\mathbf{1 0 0 , 0} \%$ \\
\hline
\end{tabular}

Source: Research results. 
ISSN-PRINT

1794-9831

E-ISSN 2322-7028

Vol. 16 No. 3

Sep - Dic 2019

Cúcuta, Colombia
To calculate the functional ability compromise, the Barthel scale was used and to calculate the comorbidity the functional comorbidity index was considered (24). In that sense, 1005 of the population objects of study had a Barthel scale lower than 50, considered as severe and total dependence and a high comorbidity index, consequence of multiple pathologies. Regarding the INR at the beginning of the program, $60 \%$ of people came to the program outside the therapeutic range, either due to under-anticoagulation or over anticoagulation (See Table 4 ).

Table 4. Frequency distributions and percentages about the INR at the beginning of the anticoagulation domiciliary program. Bogota, Colombia.

\begin{tabular}{ccc}
\hline INR Value & Frequency & Percentage \\
\hline INR $<1,9$ (Subtherapeutic) & 36 & $54,5 \%$ \\
INR ENTRE 2 Y 3,5 (Therapeutic) & 26 & $39,4 \%$ \\
INR $>3,5$ (Supratherapeutic) & 4 & $6,1 \%$ \\
Total & $\mathbf{6 6}$ & $\mathbf{1 0 0 , 0} \%$ \\
\hline
\end{tabular}

Source: Research results.

The bleeding risk was calculated through the HASBLED scoring system. This score allows the determination of bleeding risk by analyzing variables such as blood pressure, renal and liver function, stroke precedents, bleeding history, INR lability, age, use of medicines and alcohol consumption. Each variable assigns a score and weighs the risk of bleeding as low, intermediate or high (25). In the specific case of this program, $94 \%$ of people came with high and intermediate risk of bleeding, $54 \%$ showed a high risk of bleeding, $40 \%$ an intermediate risk of bleeding, and 6\% low risk. Since the admission to the domiciliary anticoagulation program and their uninterrupted permanence for 12 months, the following results were obtained:

Once the person is admitted to the program, INR and PT controls begin every 72 hours during the first days or until obtaining the therapeutic range. $80 \%$ of the people achieved their therapeutic target in the first 9 days after being admitted and around $8 \%$ did not reach the target. These people, although getting control and accompaniment from the program were not able to reach the target, are reevaluated and rotated to direct anticoagulants or heparins of low molecular weight, according to indications (See table 5).

Table 5. Frequency distributions and percentages about necessary controls to achieve the therapeutic range of the participants. Bogota, Colombia.

\begin{tabular}{ccc}
\hline Number of controls & Frequency & Percentage \\
\hline 1 & 28 & $42 \%$ \\
2 & 24 & $36 \%$ \\
3 & 8 & $12 \%$ \\
4 & 2 & $3 \%$ \\
8 & 1 & $2 \%$ \\
Did not reach the range & 3 & $5 \%$ \\
Total & $\mathbf{6 6}$ & $\mathbf{1 0 0} \%$ \\
\hline
\end{tabular}

Source: Research results

The time in therapeutic range corresponds to the time the patient stays at the therapeutic target and constitutes a tracing indicator by excellence of the success of the anticoagulant therapy (26). People attended in this program achieved a time in therapeutic range of $70 \%$, with at least 12 controls performed from October 2016 to November 2017. 
In relation to the proportion of adverse events as an indicator of security for the program, the results demonstrate that during the period of performance of this study, there were no adverse events requiring hospitalization, additional therapeutic interventions, presence of bleeding or new thrombotic events.

\section{Discussion}

The anticoagulant therapy represents the cornerstone in the treatment and prevention of thrombotic diseases and coagulation disorders, as stated Pantaleon and collaborators, showing that oral anticoagulants have demonstrated to be efficient for the prevention of thrombotic diseases. Its use has significantly increased and its currently considered as the medicine of preference for prevention and treatment, in the long term, of thrombosis or embolism (27).

The results of this study, where $70 \%$ of people attended are anticoagulated with warfarin, coincide with similar studies that assure that warfarin is the most used medicine, consequence of clinical experience and economic cost, in spite of its narrow margin of security, the need for permanent monitoring and interaction with food and medicines, and parallel to the emergence of direct oral anticoagulants since 2008, as asserted by Bejarano et al. in a study performed in the city of Bogota (28).

Studies about the use of anticoagulants in Latin America confirm this information. Gamero et al., in a study performed in Peru in 2017, found that $95 \%$ of people with oral anticoagulation received warfarin and only $5 \%$ took direct oral anticoagulants, attributing this phenomenon to a subject of costs (29).

To that effect, a study lead by members of the Medicine Faculty of the National University of Colombia, affirms that warfarin continues to be the most used oral anticoagulant in spite of its already known therapeutic limitations. However, the use of direct oral anticoagulants is becoming more frequent in spite of the cost and the lack of availability in the Beneficial Health Plan (30).

The success of anticoagulant therapy and the reduction of preventable adverse events, specifically with the warfarin therapy, could be explained, in a large extent, to the health education and periodic monitoring of INR and PT, as well as the existence of a direct channel of direct communication with the health team. This coincides with the results of a study made in Chile by Castro et al., who emphasize that the quality of the oral anticoagulant treatment is firmly related not only with the incidence of embolic and thrombosis complications but also with the gravity of these, being frequent monitoring necessary (31). In that sense, Miranda et al., agree with the monitorization and the strict control of the anticoagulant therapy, reducing the risk of thrombotic events or bleeding (32). However, it is necessary to advance in the research target of the studies to demonstrate the impact of the research programs, exceeding the descriptive and advancing towards the correlational and even towards the experimental areas, with a strict control of the variables.

The analysis of the gender distribution shows that two out of the three most frequent anticoagulation indications are mainly present in males. Therefore, atrial fibrillation is the most prevalent arrythmia and mainly affects men $(33,34)$, coinciding with the data from the Colombian Society of Cardiology and Cardiovascular Surgery, the American Heart Association and the European Society of Cardiology (4), as well as the event of ischemic stroke (35), and, differing from deep vein thrombosis, which affects more women (36) than men. For being a program where more than $70 \%$ of the people exceeds 70 years of age, its most frequent to find women, given the characteristics of life expectancy in Colombia, where the female gender lives longer (37).

This study reports a time in therapeutic range of $70 \%$, higher than in other studies such as the TERRA study made in Argentina, which analyzed data of time in therapeutic range of 14 anticoagulation programs and reported $66 \%$ (38). Meanwhile, in the study performed in the Fundacion de Santa Fe University Hospital in Bogota, with a total of 159 patients, the time in therapeutic range obtained was of $53.7 \%$ (17). A similar result was obtained at the San Vicente Fundacion de Medellin University Hospital, with 54\% of time in therapeutic range, with more than 6 controls performed in the anticoagulation clinic (32).

Regarding the security indicators of the program, the results show that during the performance of this study no adverse events were present. However, the fact that the population achieved a time in therapeutic range of $70 \%$ means that $30 \%$ of the time this was outside the target, interpreting it as an incident. At 
ISSN-PRINT

1794-9831

E-ISSN 2322-7028

Vol. 16 No. 3

Sep - Dic 2019

Cúcuta, Colombia this point, it is important to emphasize that once the PT and INR controls are performed at the residence of the person and immediately reported, a convenient adjustment of the doses is allowed, limiting the event to an incident, constituting an original characteristic of this program.

Agreeing with the latter, Somonetti et al., affirm that health promotion is a key strategy for the prevention of thromboembolic events in patients with oral anticoagulation therapy. In this context, the nurses and doctors perform the role of educators, particularly by providing a clear orientation about risk facts and possible signs and symptoms, also the complications related to anticoagulation (39).

Describing the characteristics of an anticoagulation domiciliary program -phenomena that is not found in literature-, takes special interest since the domiciliary environment is a new space in which health has been advancing, making more often the hospital visit the home of the patient and demonstrating a positive impact in the health indicators, as affirmed by Gomez et al., who assure that domiciliary attention decreases the workload of the caregiver, favors the psychological health of the patient, lowers the attention costs and improves the level of satisfaction of the users (40).

\section{Conclusions}

- Warfarin is still the most used anticoagulant, due to clinical experience, cost and inclusion in the health benefits plan, despite the requirement of permanent monitoring, ample lability and interaction with other medicine and foods.

- $70 \%$ of people attended at the program were women and $30 \%$ were men, exceeding the age of
60. In relation to the anticoagulation indications, atrial fibrillation is the predominant phenomenon, followed by ischemic stroke and DVT. However, around $42 \%$ of people present more than one anticoagulation indication. $60 \%$ of people are admitted outside the therapeutic range and $94 \%$ present intermediate and high risk of bleeding.

- Subsequent to the admission to the anticoagulation domiciliary program, $80 \%$ of the patients achieved their INR therapeutic target before the ninth day and around $8 \%$ did not accomplish the target, requiring rotation to direct oral anticoagulants or heparins of low molecular weight.

- A 70\% of time in therapeutic range was achieved with at least 12 controls performed between October 2016 and November 2017 -a higher range compared to similar studies-, reaffirming the importance of permanent monitoring, the existence of a direct communication channel between the patient, the family and the heath team from the program, the availability of additional controls and immediate adjustments at the residence, without needing to wait for a doctor's appointment or having to move to the clinic or hospital.

- The PT + INR control performed at the residence of the patient and reported immediately to the health team, allows the appropriate adjustment of doses, preventing the emergence of adverse events and limiting these, in the worst case scenario, to an incident.

\section{Conflict of interest}

The authors declare not having any conflict of interest

\section{Bibliographic References}

1. Fernández Capitán MC. Epidemiologia de las enfermedades tromboembólicas: fibrilación auricular, enfermedad tromboembólica venosa y síndrome coronario agudo. Med Clin [Internet]. 2012 [Consultado10 jun 2018]; 139 (2):4-9. Disponible en: http://www.elsevier.es/es-revista-medicina-clinica2-articulo-epidemiologia-las-enfermedades-tromboembolicas-fibrilacion-S0025775312700349

2. García Prieto M, Maseda A, Sánchez A, Lorenzo López L, Núñez Naveira L, Millán Calenti JC. Enfermedad tromboembólica venosa en personas mayores: revisión de la literatura. Gerokomos [Internet]. 2014 [Consultado 10 jun 2018]; 25 (3): 93-97. Disponible en: http://scielo.isciii.es/scielo. php?script $=$ sci arttext\&pid $=$ S1134-928X2014000300002

3. Wilches N, Rojas MC, Mesa AM, Fajardo LA, Gallego C. Trombólisis intraparo en tromboembolia 
pulmonar masiva. Rev. Colomb. Cardiol. [Internet]. 2018 [Consultado 10 jun 2018]; 25 (2): 152e1-

152e6 Disponible en: http://www.elsevier.es/es-revista-revista-colombiana-cardiologia-203-articulotrombolisis-intraparo-tromboembolia-pulmonar-masiva-S0120563317301341

4. Mantilla Villabona LY, Ospina Galeano DC, Gutiérrez Ortiz AJ, Camacho PA. Pacientes con fibrilación auricular atendidos en consulta de atención primaria de una institución de alta complejidad. Rev. Colomb. Cardiol [Internet]. 2018 [Consultado 10 jun 2018]; 25 (2): 124-30. Disponible en: https:// www.sciencedirect.com/science/article/pii/S0120563317302097?via\%3Dihub

5. Beltrán A, Galain G, Pouso M. Reclasificación de la severidad de la estenosis aórtica con la utilización del enfoque paraesternal derecho con transductor ciego. Rev. Urug. Cardiol [Internet]. 2017 [Consultado 14 jun 2018]; 32 (3): 258-63. Disponible en: http://www.suc.org.uy/revista/V32N3/pdf/ rcv32n3 beltran-estenosis.pdf

6. Organización Mundial de la Salud. Las 10 principales causas de defunción [internet]. Ginebra: Suiza. 2018 [Consultado 14 jun 2018]. Disponible en: http://www.who.int/mediacentre/factsheets/fs310/es/

7. Silva F, Quintero C, Zarruk JG. Guía neurológica 8, Capitulo 2 Comportamiento Epidemiológico de la Enfermedad Cerebrovascular en la Población Colombiana [Internet]. Colombia [Consultado 14 jun 2018]. Disponible en: http://www.acnweb.org/guia/g8cap2.pdf

8. Noroña Calvachi CD. Trombofilias hereditarias. Rev Cient Cienc Méd [Internet]. 2015 [Consultado 14 jun 2018]; 18 (1): 43-49. Disponible en: https://www.redalyc.org/articulo.oa?id=426041256009

9. Valdés Naranjo Y, Pantaleón Bernal OS. Adherencia terapéutica a los anticoagulantes orales y su importancia en la enfermedad tromboembólica venosa. Rev Cubana Angiol Cir Vasc [Internet]. 2016 [Consultado 14 jun 2018]; 17 (1): 55-70. Disponible en: http://scielo.sld.cu/scielo.php?script=sci_artt ext\&pid $=$ S1682-00372016000100008

10. Laverde LP, Gómez SE, Montenegro AC, Lineros A, Wills B, Buitrago AF. Experiencia de una clínica de anticoagulación. Rev Colomb Cardiol [Internet]. 2015 [Consultado 16 jun 2018]; 22 (5): 224-30. Disponible en: https://www.sciencedirect.com/science/article/pii/S0120563315000984?via\%3Dihub

11. Romero Ruiz A, Parrado Borrego G, Rodríguez González J, Caparrós Miranda IS, Vargas Lirio MI, Ortiz Fernández P. La consulta de terapia antitrombótica: progresando hacia la Enfermería de Práctica Avanzada. Enferm Clin [Internet]. 2014 [Consultado 18 jun 2018]; 24: 200-4. Disponible en: https:// www.sciencedirect.com/science/article/pii/S1130862114000369?via\%3Dihub

12. Mendoza JA, Silva FA, Ortiz Castro CH, Rangel LM. Revisión sistemática de nuevos anticoagulantes orales frente a warfarina en fibrilación auricular no valvular. Acta Neurol Colomb [Internet]. 2017 [Consultado 20 jun 2018]; 33 (3): 188-98. Disponible en: https://www.acnweb.org/es/acta-neurologica-colombiana/1516-revision-sistematica-de-nuevos-anticoagulantes-orales-frente-a-warfarina-enfibrilacion-auricular-no-valvular.html

13. Andrade MV, Andrade LA, Bispo A, Freitas L, Andrade M, Feitosa G, et al. Evaluation of the Bleeding Intensity of Patients Anticoagulated with Warfarin or Dabigatran Undergoing Dental Procedures. Arq. Bras. Cardiol. [Internet]. 2018 Sep [Consultado 21 feb 2019]; 111 (3): 394-399. Disponible en: http:// www.scielo.br/scielo.php?script=sci arttext\&pid=S0066-782X2018001500394\&lng=en

14. Vargas González JC, Colina Murillo MN, Fajardo Torres JA. Costo utilidad en Colombia del uso de los nuevos anticoagulantes orales comparados con los antagonistas de la vitamina $\mathrm{K}$ para la prevención de discapacidad por ataque cerebrovascular en pacientes con fibrilación auricular no valvular. Acta Neurol Colomb [Internet]. 2016 [Consultado 22 jun 2018]; 32 (4): 297-304. Disponible en: http://www. scielo.org.co/pdf/anco/v32n4/v32n4a05.pdf

15. Rada MC, Mandrá M, Tomas F, Rollan I, Floridia J, Herrera G. Indicación de anticoagulación en la práctica diaria de médicos neurólogos de la ciudad de Salta. Neurol Arg [Internet]. 2016 [Consultado 22 jun 2018]; 8: 101-4. Disponible en: https://www.sciencedirect.com/science/article/abs/pii/ $\underline{\text { S1853002816000379?via\%3Dihub }}$ 
ISSN-PRINT

$1794-9831$

E-ISSN 2322-7028

Vol. 16 No. 3

Sep - Dic 2019

Cúcuta, Colombia

16. Ocampo Kohn C, Hernández Ortiz O, Velásquez Franco CJ, Tobón Acosta I, Mejía Restrepo FA. La clínica de anticoagulación del Hospital Universitario San Vicente de Paúl: demografía, efectividad y complicaciones. Iatreia [Internet]. 2004 [Consultado 22 jun 2018]; 17 (2): 105-14. Disponible en: https://aprendeenlinea.udea.edu.co/revistas/index.php/iatreia/article/viewFile/4047/3762

17. Taboada LB, Silva LE, Montenegro AC. Beneficios de la clínica de anticoagulación. Acta Med Colomb [Internet]. 2013 [Consultado 24 jun 2018]; 28 (4): 239-43. Disponible en: http://www.scielo.org. co/pdf/amc/v38n4/v38n4a10.pdf

18. Ministerio de Salud y Protección Social de la República de Colombia. Resolución 2003 de 2014 "Por la cual se definen los procedimientos y condiciones de inscripción de los Prestadores de Servicios de Salud y de habilitación de servicios de salud" [Internet]. Bogotá: Colombia. 2014 [Consultado 24 jun 2018]. Disponible en: www.minsalud.gov.co/Normatividad_Nuevo/Resolución $\% 202003 \% 20 \mathrm{de} \% 20$ 2014.pdf

19. Organización Panamericana de la Salud. Conferencia Internacional sobre Atención Primaria de Salud, Alma-Ata, URSS, 6-12 de septiembre de 1978 [Internet]. Washington. 2012 [Consultado 26 jun 2018]. Disponible en: https://www.paho.org/hq/dmdocuments/2012/Alma-Ata-1978Declaracion.pdf

20. Guevara Francesa G, Solís Cordero K. Visita domiciliaria: un espacio para la adquisición y modificación de prácticas en salud. Rev. costarric. salud pública [Internet]. 2017 [Consultado 24 jun 2018]; 26 (2): 163-80. Disponible en: https://revistas.ucr.ac.cr/index.php/enfermeria/article/view/31772

21. Duboscq C, Ceresetto JM, Stemmelin G, Shanley C, Rabinovich O, Palmer S, et al. Evaluación del desempeño de un dispositivo portátil para la determinación de la razón internacional normalizada. Hematología [Internet]. 2014 [Consultado 24 jun 2018]; 18 (3): 204-10. Disponible en: http://www. sah.org.ar/revista/numeros/vol.18n.3.204.210.pdf

22. Chiquette E, Amato MG, Bussey HI. Comparison of an anticoagulation clinic with usual medical care: anticoagulation control, patient outcomes, and health care costs. Arch Intern Med [Internet]. 1998 [Consultado 28 jun 2018]; 158 (15): 1641-7. Disponible en: https://jamanetwork.com/journals/ jamainternalmedicine/fullarticle/1105598

23. Ministerio de Salud y Protección Social de la República de Colombia. Resolución 8430 de 1993 "Por la cual se establecen las normas científicas, técnicas y administrativas para la investigación en salud" [Internet]. Colombia. 1993 [Consultado 30 jun 2018]; Disponible en: https://www.minsalud.gov.co/ sites/rid/Lists/BibliotecaDigital/RIDE/DE/DIJ/RESOLUCION-8430-DE-1993.PDF

24. Tuesta Nole JR, Cieza Macedo EC. Predictores de mortalidad a los seis meses del alta de una Unidad Geriátrica de Agudos, 2016. Horiz. Med [Internet]. 2017 [Consultado 5 ago 2018]; 17 (4): 19-23. Disponible en: http://www.horizontemedicina.usmp.edu.pe/index.php/horizontemed/article/view/696

25. Ferreira Beltrame RC, Bandeira Giasson FT, Azeredo da Silva AL, Gomes BS, Amon LC, Bergamini-Blaya M, et al. Use of HAS-BLED Score in an Anticoagulation Outpatient Clinic of a Tertiary Hospital. Int. J. Cardiovasc. Sci [Internet]. 2017 [Consultado 5 ago 2018]; 30 (6): 517-52. Disponible en: http://www.scielo.br/scielo.php?script=sci_arttext\&pid=S2359-56472017000600517

26. Gómez A, Peixoto S, Azcúnaga M, Gama A, Lluberas N, Álvarez P. Calidad de la anticoagulación oral con warfarina en una policlínica de cardiología: porcentaje de tiempo en rango terapéutico. Rev.Urug. Cardiol [Internet]. 2014 Dic [Consultado 31 ene 2019]; 29 (3): 311-316. Disponible en: http://www. scielo.edu.uy/scielo.php?script=sci_arttext\&pid=S1688-04202014000300006\&lng=es.

27. Pantaleón Bernal O, Triana Mantilla ME, Aldama Figueroa A, Valdés Naranjo Y. Control del tratamiento anticoagulante oral en población geriátrica con enfermedad tromboembólica venosa. $\mathrm{Rev} \mathrm{Cu}-$ bana Angiol Cir Vasc [Internet]. 2015 [Consultado 9 ago 2018]; 16 (1): 44-53. Disponible en: http:// scielo.sld.cu/pdf/ang/v16n1/ang07115.pdf

28. Bejarano Zuleta A, Aguiar L, Pulido J, Ruiz A. Experiencia de uso de complejo protrombínico en la reversión de los pacientes anticoagulados con warfarina en el servicio de urgencias en un hospital de 
IV nivel. Acta Colombiana de cuidado intensivo [Internet]. 2016 [Consultado 13 ago 2018]; 16 (4): 247-53. Disponible en: https://www.sciencedirect.com/science/article/pii/S0122726216300684

29. Gamero MT, Cornejo M, Dueñas R, Samalvides F. Factores asociados a la anticoagulación oral óptima en el adulto mayor con fibrilación auricular. Rev Med Hered [Internet]. 2017 [Consultado 30 jun 2018]; 28: 84-92. Disponible en: http://www.upch.edu.pe/vrinve/dugic/revistas/index.php/RMH/ article/view/3108/3079

30. Jaramillo Salamanca RR, Jiménez Gómez JD, Pinilla Roa AE. Uso de los anticoagulantes orales directos en la práctica clínica. Rev Fac Med [Internet]. 2016 [Consultado 30 jun 2018]; 64 (2): 295-308. Disponible en: http://www.scielo.org.co/pdf/rfmun/v64n2/v64n2a15.pdf

31. Castro C, Bustos L, Ocampo R, Molina E, Cabrero P, Vergara R, et al. Efectividad y seguridad del tratamiento anticoagulante con acenocumarol en fibrilación auricular no valvular. Rev. méd. Chile [Internet]. 2017 [Consultado 15 ago 2018]; 145 (10): 1243-51. Disponible en: https://scielo.conicyt.cl/ scielo.php?script $=$ sci arttext\&pid=S0034-98872017001001243\&lng=en\&nrm =iso\&tlng=en

32. Miranda H, Osório S, Giraldo DP, Duque J, Ubeimar Cataño J, Tobón LI, et al. Tiempo en rango terapéutico (TRT) en clínica de anticoagulación. Reportes de eventos adversos y factores asociados a bajo TRT. Acta Med Colomb [Internet]. 2016 [Consultado 15 ago 2018]; 41 (1): 42-48. Disponible en: http://www.scielo.org.co/pdf/amc/v41n1/0120-2448-amc-41-01-00042.pdf.

33. Groll DL, To T, Bombardier C, Wright JG. The development of a comorbidity index with physical function as the outcome. J Clin Epidemiol [Internet]. 2005 [Cited 1 aug 2018]; 58 (6): 595-602. Available from: https://www.jclinepi.com/article/S0895-4356(05)00021-1/fulltext

34. Alireza N. Clinical Challenges of Using Novel Oral Anticoagulants for Stroke Prevention in Patients with Atrial Fibrillation. Tex Heart Inst J [Cited 1 aug 2018]. 2018; 45 (3): 164-165. Available from: https:/www.ncbi.nlm.nih.gov/pmc/articles/PMC6059508/pdf/i1526-6702-45-3-164.pdf

35. Bonilla NP, Oliveros H, Proaños J, Espinel B, Álvarez JC, Duran C, et al. Estudio de frecuencia de los factores de riesgo asociados al desarrollo de enfermedad cerebrovascular isquémica no embolica en un hospital de tercer nivel. Acta. Neurol. Colomb [Internet]. 2014; 30 (3):149-155. Disponible en: http:// www.scielo.org.co/pdf/anco/v30n3/v30n3a04.pdf

36. Becker CA, Fernández RA, Paolantonio J, Lerman M, Ucedo EG, Ávila R, et al. Registro prospectivo de estrategias diagnósticas implementadas para tromboembolia venosa en servicios de medicina intensiva de Santa Fe. Rev Argent Cardiol [Internet]. 2014 [Consultado 1 ago 2018]; 82: 218-24. Disponible en: http://ppct.caicyt.gov.ar/index.php/rac/article/view/1692/pdf

37. Rivillas JC, Gómez Aristizábal L, Rengifo Reina HA, Muñoz Laverde EP. Envejecimiento poblacional y desigualdades sociales en la mortalidad del adulto mayor en Colombia ¿Por qué abordarlos ahora y dónde comenzar? Rev. Fac. Nac. Salud Pública [Internet]. 2017 [Consultado 1 ago 2018]; 35(3): 36981. Disponible en: http://aprendeenlinea.udea.edu.co/revistas/index.php/fnsp/article/view/325933

38. Cd T, Jm C, Bottaro F, Martí A, Casey M. Evaluación del tiempo en rango terapéutico en pacientes con fibrilación auricular tratados crónicamente con antagonistas de la vitamina $\mathrm{K}$ por especialistas en hemostasia de la Argentina. Hematología [Internet]. 2016 [Consultado 5 ago 2018]; 20 (1): 9-26. Disponible en: http://www.sah.org.ar/revista/numeros/01\%20vol\%2020\%202016.pdf

39. Simonetti SH, Faro AC, Bianchi ER. Adherence score for Users of Oral Anticoagulants. Int. J. Cardiovasc. Sci. [Internet]. 2018 Aug [cited 26 sep 2018]; 31 (4): 383-392. Available from: http://www. scielo.br/scielo.php?script $=$ sci arttext\&pid $=$ S2359-56472018000400383\&lng=en.

40. Puchi Gómez C, Paravic Klijn T, Salazar A. Indicadores de calidad de la atención en salud en hospitalización domiciliaria: revisión integradora. Aquichan [Internet]. 2018 [cited 4 feb 2019]; 18 (2): 186-197. Available from: http://www.scielo.org.co/scielo.php?script=sci arttext\&pid=S1657$\underline{59972018000200186 \& \operatorname{lng}=\mathrm{en}}$ 